\title{
PSYCHOLOGICAL CHARACTERISTICS OF PARENTS OF PROBLEM CHILDREN
}

\author{
Myroslava Mushkevych \\ Lesya Ukrainka Eastern European National University \\ Volya Avenue, 13, Lutsk, 43025, Ukraine \\ E-mail:mira_mush@yahoo.com,https://orcid.org/0000-0002-3268-5767
}

The article presents the investigation of the characteristics of the personality and emotional sphere of parents having problem children and identify the relationship of these features with respect to children. The scientifically based material presented in the article provides statistical analysis of the data obtained during the factorization of the source empirical data obtained with the help of standardized assessment means. The subject of statistical analysis at this stage was to test the hypothesis of significant differences in the level of severity of personality factors of the subjects, grouped in different categories based on gender, age, family status and family functioning. In particular, reliable differences in the level of personality factors in the subjects of different sexes were found in relation to «constructive educational protection», «indulgently indifferent personal disposition», «passive-protective personal disposition» and «psychosthenic personal disposition». Statistically significant differences in the level of personality factors in the subjects with different family status were detected in relation to «extroverted personality disposition», «the indulgent educational disposition» and «constructive educational support». According to the results of the statistical analysis of age characteristics of the expressiveness of the personal factors of the parents of the problem children, statistically significant differences were identified according to the factor of «constructive educational protection», «introverted-pedantic personal disposition» and «indulgent educational disposition». The statistical analysis of the indicators of the severity of personality factors in the subjects with different types of family functioning allowed to reveal statistically significant differences in a number of factors: «major educational disposition», «constructive educational protection», and «Introverted-pedantic personal disposition».

KEYWORDS: family functioning, family status, problem children, personal disposition, statistical analysis.

\section{ПСИХОЛОГІЧНІ ХАРАКТЕРИСТИКИ БАТЬКІВ ПРОБЛЕМНИХ ДІТЕЙ}

Мушкевич М.I. Східноєвропейський національний університет імені Лесі Украйнки проспект Волі, 13, Луиььк, 43025, Україна

Стаття присвячена дослідженню характеристик особистості та емоційної сфери батьків, які мають проблемних дітей, та визначає взаємозв'язок цих особливостей з дітьми. На основі науково обгрунтованого матеріалу, представленого в статті, статистичний аналіз даних, отриманих під час факторизації вихідного емпіричного фактажу, отриманого за допомогою стандартизованих психодіагностичних засобів. Предметом статистичного аналізу на цьому етапі було тестування гіпотези суттєвих відмінностей у ступені вираженості факторів особистості суб'єктів, згрупованих у різних категоріях за ознаками статі, віку, сімейного статусу та функціонування сім'ї. Зокрема, були виявлені достовірні відмінності в рівні особистісних чинників у суб'єктів різних статей щодо «конструктивного захисту», «поблажливо індиферентного особистого ставлення», «пасивно-захисної особистісної диспозиції» та «психостонічного особистого ставлення». Встановлено статистично значущі відмінності в рівні факторів особистості у субє'ктів з різним сімейним статусом у зв'язку з «екстравертованим розподілом особистості», «поблажливим виховним становищем» та «конструктивним виховним забезпеченням». Згідно з результатами статистичного аналізу вікових характеристик виразності особистих факторів батьків проблеми дітей виявлено статистично значущі відмінності за фактором «конструктивного виховного захисту», «інтровертно-педантичного особистого ставлення» та «поблажливого виховного розташування». Статистичний аналіз показників тяжкості факторів особистості у суб' єктів 3 різними типами функціонування сім’ї дозволив виявити статистично значущі відмінності в ряді факторів: «основне виховне розташування», «конструктивний виховний захист» та «інтровертно-педантичний особистісний стиль».

КЛЮЧОВІ СЛОВА: функціонування сім’ї, сімейний стан, проблемні діти, особистісна диспозиція, статистичний аналіз.

\section{ПСИХОЛОГИЧЕСКИЕ ХАРАКТЕРИСТИКИ РОДИТЕЛЕЙ ПРОБЛЕМНЫХ ДЕТЕЙ}

Мушкевич М.И. Восточно-Европейский Национальный Университет имени Леси Украинки проспект Воли, 13, Луик, 43025, Украина

В статье представлено исследование характеристик личности и эмоциональной сферы родителей, имеющих проблемных детей. Научно обоснованный материал обеспечивает статистический анализ данных, полученных при факторизации исходного эмпирического исследования с помощью стандартизированных психодиагностических методик. Предметом 
статистического анализа на данном этапе было проверить гипотезу о значительных различиях в уровне выражености личностных факторов субъектов, сгруппированных в разные категории по признаку пола, возраста, семейного положения и функционирования семьи. Были обнаружены достоверные различия в уровне личностных факторов у субъектов разных полов в отношении «конструктивной воспитательной защиты», «снисходительного индифферентного личностного расположения», «пассивно-защитного личного расположения» и «психостенического личного расположения». Статистически значимые различия в уровне личностных факторов у субъектов с различным семейным статусом были обнаружены в связи с «экстравертированной индивидуальностью личности», «снисходительным воспитательным укладом» и «конструктивной воспитательной поддержкой». По результатам статистического анализа возрастных характеристик выразительности личностных факторов родителей проблемных детей статистически значимые различия были выявлены в соответствии с фактором «конструктивной образовательной защиты», «интровертно-педантским личным характером» и «снисходительное воспитание». Статистический анализ показателей тяжести личностных факторов у субъектов с различными типами функционирования семьи позволил выявить статистически значимые различия по ряду факторов: «основная воспитательная дислокация», «конструктивное защитное воспитание» и «интровертно-педантичный личный настрой».

КЛЮЧЕВЫЕ СЛОВА: семейное положение, семейный статус, проблемные дети, личные факторы, статистический анализ.

Introduction. A number of negative factors influence the socio-psychological state of modern Ukrainian society. Those are: the economic and ecological crisis, natural disasters, as well as related migration, changing living conditions, revaluation of social and individual values, which in turn reflects on the situation of the family, the purpose and objectives of the upbringing and development of children, parent-child relationships, parenting styles. In the plan of our study, these characteristics relate to families with problem children. The Ukrainian tradition of helping families with problematic children is concentrated primarily on the child himself, when the family - both nuclear and expanded - remains only a resource, a condition or an obstacle. This approach to family B. Schmidt calls instrumental [8]. The works of Ukrainian and foreign researchers (M. Boryshevsky; Varga, 2000; Garbuzov, 2013; T. Govorun; Eidemiller, 2009; Zakharov, 2010; A. Shargan; Yatsenko, 2015) and others convincingly depict the dependence of the formation of the child's personality from the style of parenting in the family, parental attitude to the child, ways of family communication. The peculiarities of families with a problematic child were considered by (Bogdanova, 2012), (Mayramyan, Mamaychuk 2006), (Mastyukova, Semago, 2000) and others in their works. However, these studies were limited only to the need to develop special measures aimed at rehabilitating this category of children, as well as offering correction and further counseling for the parents by the experts of various profiles (psychologists, educators, doctors). The urgency of the problem of this study is, first of all, in the need to determine the characteristics of the personality and emotional sphere of parents having problem children and to identify the relationship of these features with respect to children. In our investigation "problem child» is one that creates inconveniences for the functioning of adults (parents, grandparents, educators, teachers, others), as it is characterized by such features as shamefulness, activeness, aggressiveness, disrespectfulness, disobedient, impulsiveness, irresponsibleness, etc. (aged 5 to 9 years).

The aim of scientifically based material presented in the article provides statistical analysis of the data obtained during the factorization of the source of such empirical data as character accentuations, a parental attitude, and family relationships in the families that have a problem child.

Materials and Methods. The research was conducted on the basis of the Psychological Consulting Center at the Practical and Clinical Psychology Department of Lesya Ukrainka East European National University. The sample consisted of 450 parents aged from 27 to 56 years, among them women - 60.7\%, men 39.3\%. All parents turned for psychological help.

The empirical investigation was obtained with the help of such standardized psychodiagnostic means as a test questionnaire for the study of character accentuations (A. Egides in the modification of I. Slobodyanyuk, O. Kholodova, O. Oleksenko), a test-questionnaire for the study of parental attitude (A. Varga, V. Stolin), a test-questionnaire for the analysis of family relationships (E. Eidemiller, V. Yustitsky), Freiburg's Personality Inventory (FPI). 
The subject of statistical analysis at this stage was to test the hypothesis of significant differences in the level of severity of personality factors of the subjects, grouped in different categories based on gender, age, family status and family functioning. In particular, the following statistical methods were used in our study: a) for comparison of average values of personality factors in the studied different groups - a method of comparing mean values (Compare Means) (Nasledov A.D. (2004); b) to determine the true differences in the mean values of the individual factors of the subjects studied, differentiated according to the criterion of «sex» (wifehusband) and «family status» (incomplete, complete family), - nonparametric criterion for differences for independent Mann-Whitney samples (Mann-Whitney Test) (Nasledov, 2005); c) to determine the true differences in the mean values of the individual factors of the subjects, differentiated according to the age criterion, is a nonparametric criterion for differences for directed (ordered) alternatives Jonckheere-Terpstra Test (Nasledov, 2004; Nasledov, 2005). The argument in favor of the choice of this statistical method is that it allows not only to compare the samples among themselves in order to determine the true differences between the measured features, but also to identify certain tendencies (trends) in the results, which are the result of the actions of any orderly in their gradation factor. Actually, such factor in our study is the indicator of age of the subjects; d) for the determination of statistically significant differences in the mean values of personal factors of the subjects, differentiated by the level of family functioning (pseudo-functional, dysfunctional, functional family), - non-parametric criterion of differences for non-directed (disordered) Kruskal-Wallis alternatives (Kruskal-Wallist Test) (Nasledov, 2004; Nasledov, 2005).

Note that when comparing the average values of personality factors of the subjects, the average values of their factor estimates pre-calculated at the final stage of the factorization of empirical data were used. In this case, factor estimation is a quantitative measure of the severity of the personal factor presented in units of standard deviation, so the average value of the factor will range from -3 to +3 .

Results. Comparison of average values of personal factors of parents having problem children, on the subject of gender-specific differences has revealed a number of important trends. So, depending on gender, the average values of their personal factors were distributed as follows (Table 1).

Table 1

The average values of the personality factors of the subjects in accordance with sex

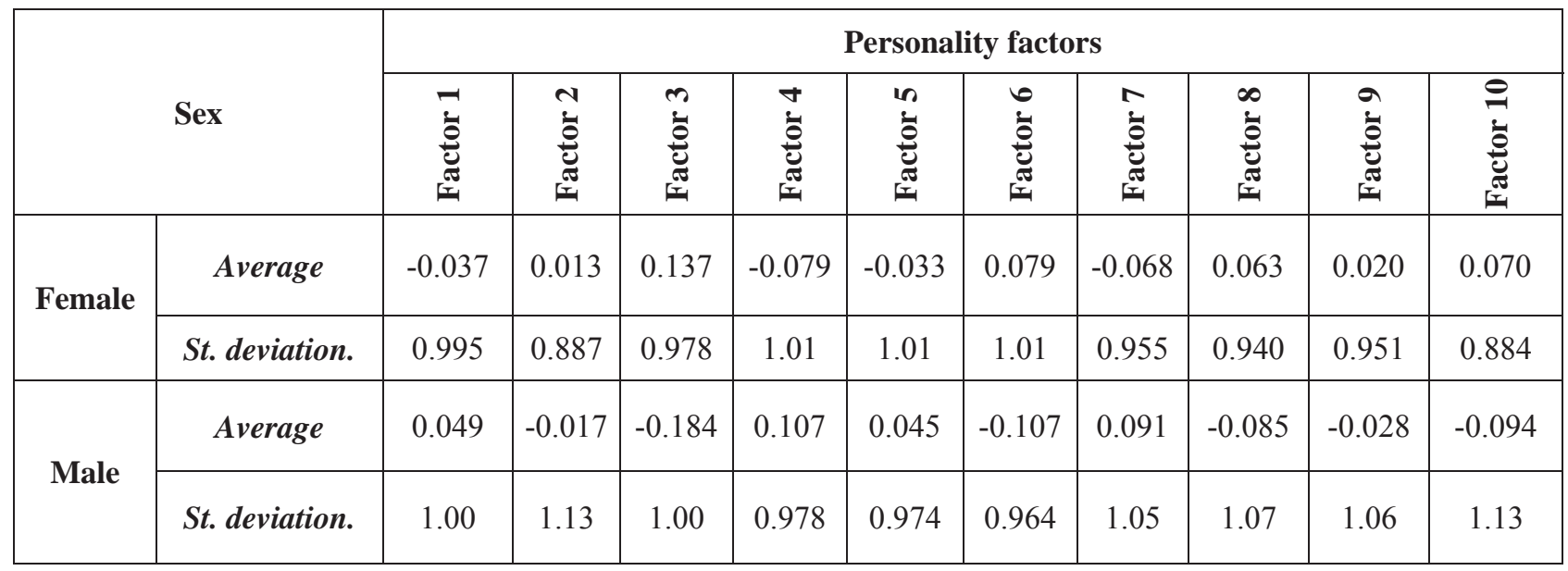

Factor 1 - «authoritarian educational disposition». Factor 2 - «the most powerful educational disposition». Factor 3 «constructive educational support». Factor 4 - «psychasthenic personal disposition». Factor 5 - «ambivalent personality disposition». Factor 6 - «indulgent-indifferent personal disposition». Factor 7 - «dominantly aggressive personal disposition». Factor 8 - «extravagant personality disposition». Factor 9 - «introverted pedantic personal disposition». Factor 10 - «passive-protective personality disposition».

For the sake of the correctness of further interpretation of the revealed trends, ignore the detailed analysis of those differences in the mean values of personality factors of the subjects who are not statistically 
significant. Also, taking into account the nature of the results obtained, the generalization of tabular data will be correctly conducted using the results of studying the significant differences in the level of severity of personality factors of the subjects (Table 2).

Table 2

Statistical importance of the differences in the level of expression of personal factors of the subjects in accordance with the sex

\begin{tabular}{|c|c|c|c|c|c|c|c|c|c|c|}
\hline & \multicolumn{10}{|c|}{ Personality factors } \\
\hline & $\underset{\check{c}}{\overrightarrow{0}}$ & 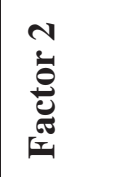 & 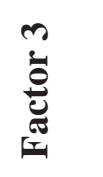 & 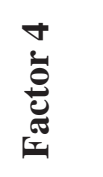 & 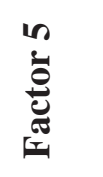 & 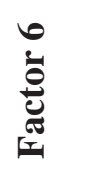 & $\stackrel{r}{\check{\Xi}}$ & 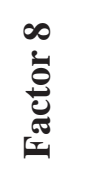 & 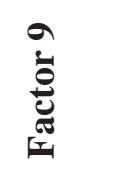 & 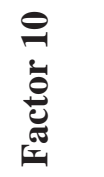 \\
\hline $\mathbf{P}$ & 0.541 & 0.653 & 0.000 & 0.044 & 0.404 & 0.018 & 0.082 & 0.271 & 0.558 & 0.034 \\
\hline
\end{tabular}

Table 2 data suggests that reliable differences in the level of expressiveness of personality factors in the subjects of different sexes were found in relation to «constructive educational support» (Factor 3$)(\mathrm{p}<0.001)$, «indulgent-indifferent personal disposition» (Factor 6) $(\mathrm{p}<0.05)$, «passive-protective personality disposition» (Factor 10) $(\mathrm{p}<0.05)$ and «psychasthenic personal disposition» (Factor 4) $(\mathrm{p}<0.05)$. Referring to the data in Table 1, it becomes apparent that women's mean values of personal factors of «constructive educational support» were significantly higher than men's (Factor 3), «condescendingly indifferent personal disposition» (Factor 6), «passive-protective personal disposition» (Factor 10). Instead, in male representatives, the higher average values were found to be due to the psychasthenic personality disposition (Factor 4).

Taking into account the meaningful characteristics of the first significant factor - «constructive educational patronage» (Factor 3) (Tables 1, 2), then it becomes apparent that female parents are more likely than male to be inclined to a high level of parental protection in the upbringing of the child. They have a more expressed desire to take an active part in the upbringing of the child; they give it more time, strength and attention; the education of such a child became for them a matter of life. Women are more likely than men to have a positive attitude towards the child, to accept the child as it is, to respect and recognize its personality, to approve its interests, to support its plans, and to be willing to spend a lot of time with it. Also, female parents are more likely to show a keen interest in what interests the child, highly appreciate its abilities, encourage its autonomy and initiative, and seek to be equal with it. In this case, women tend to reduce the psychological distance between themselves and the child as much as possible, always try to be closer to it, satisfy its basic intelligent needs, and protect it from troubles. Women will also be more likely to show hypochondriac guidelines for their children than men. Therefore, their «weakness» often leis in increased insecurity, fear of error, exaggerated perceptions about the pain of a child.

In general, it can be argued that female parents are more inclined to show a constructive and responsible parental attitude not only to parental responsibilities, but above all to the child: its needs, interests, hobbies, etc. In general, this «educational» pattern reflects the personal disposition of parents towards the upbringing of such quality in a child as: humanity, empathy, that is, those character traits that determine the moral development of the individual.

Another important factor was the «indulgent-indifferent personality disposition» (Factor 6) (Tables 1, 2). Its average values were significantly higher in women than in men. Let's turn to psychological analysis and interpretation of the revealed patterns.

Taking into account the meaningful characteristics of this personality factor, we can state that of female parents, to a greater extent than male, expressed personal tendencies towards indulgent-indifferent and nondemanding parent's attitude to the child. Usually this manifests itself in minimizing the responsibilities of children in the family. Women more often use such «educational» pattern, in which paternal education 
provides for child permissiveness, lack of requirements-prohibitions, requirements-responsibilities. For female parents a type of upbringing, in which the child is considered a small loser is more acceptable, often times treating it as an ignorant creature. The interests, hobbies, thoughts and feelings of the child seem, in this case, not serious, worthless attention, and therefore often ignored.

In general, it can be argued that female parents, in greater extent than male, showcase more of the «educative» pattern of infantile, indiscriminate, indulgent and indifferent parental attitude towards the child. Its characteristic features are often permissiveness, insufficiency of requirements-prohibitions and requirements-responsibilities.

The personal factor of the «passive-protective personal disposition» (Factor 10) was the next in terms of significance of the revealed tendencies (see Table 1-2). As in the previous case, its average values were significantly higher in women than in men. Taking into account the meaningful characteristics of this factor, then it becomes apparent that women to a greater extent than men, are characterized by a lower level of manifestation of social activity, a high level of personal neuroticism, a tendency to stress response to normal life situations, lower level of protection from exposure to stress factors. Also, female representatives show lower level of the existing need for communication and readiness to meet this need, the higher level of individual neuroticism is inherent in a greater extent. In some, unfavorable circumstances, it can be transformed into a pronounced neurotic syndrome of asthenic type with significant psychosomatic disorders. Also women, to a greater extent than men, are characterized by the tendency to stress response to normal life situations, occurring on the passive-protective type; the presence of anxiety, stiffness, uncertainty, resulting in difficulties in social contact; lower level of stress resistance, poorer protection from the stress factors of ordinary life situations, based on self-doubt and pessimism. On the basis of the abovementioned, it can be argued that women are more likely to have a passive-protective character in their personality than men.

If we take into account the meaningful characteristics of this factor 4 - «psychasthenic personal disposition», it becomes obvious that male representatives, in contrast to women, are characterized by a higher level of fearfulness, sensitivity, vulnerability, shyness, higher internal discipline, sense of duty, responsibility, self-criticism, sociability, kindness, responsiveness, and affection. In men, in comparison with women, there is also a higher level of moderation, isolation, inclination to self-deprecation, confusion in difficult situations, increased abusiveness and conflict on the grounds of offences sustained. To the line of personally significant features of the male sex, which are significantly more pronounced in comparison with women, one can include communicativeness, kindness, sensitivity, affection and sincerity. Also it is highly characteristic for them to possess a greater extent of variability of mood, the change of two opposite states - hyperthyroid, hypothymic, cyclic changes in emotional background; in the period of elevated mood - initiative, cheerfulness, sociability, or in the periods of decline mood - thoughtfulness, self-criticism. Men are also different from women in a number of other characteristic features: conscientiousness and sharp critical sight; in unfavorable circumstances, they are more abusive, vulnerable, constantly bored, display a tendency to look for manifestations of various diseases, almost complete absence of interests and hobbies. Also, men differ from women in the higher level of discretion, self-criticism, reliability, loyalty to the word, neatness, seriousness, and conscientiousness. Sometimes male representatives may show a greater degree of insecurity and anxiety, indecision, certain formalism, lack of initiative, a tendency toward endless reflections, self-examination, obsessive ideas and fears. On the basis of the abovementioned, it can be argued that males are more likely than females to have a personality symptom-complex of domination of disturbing tendencies with a manifestation of constant insecurity, indecision, fear, and vulnerability.

Turn to the definition of reliable differences in the mean values of personal factors of the subjects, differentiated according to the criterion of family status (incomplete-complete). Comparison of average values of personal factors of parents having problem children, on the status of family differences revealed a number of important trends. So, depending on the family status (incomplete-complete), the average values of their personal factors were distributed as follows (Table 3). 
Table 3

The average values of the personal factors of the subjects in accordance with the marital status

\begin{tabular}{|c|c|c|c|c|c|c|c|c|c|c|c|}
\hline \multicolumn{2}{|c|}{ Family status } & \multicolumn{10}{|c|}{ Personal factors } \\
\hline & & 范 & 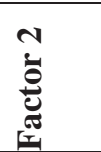 & 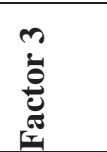 & 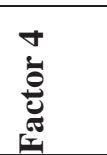 & n & 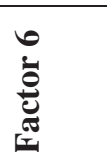 & 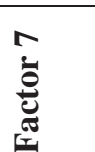 & 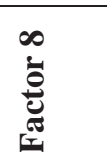 & $\underset{\tilde{\theta}}{\stackrel{0}{0}}$ & 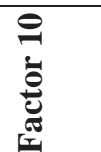 \\
\hline \multirow[b]{2}{*}{ Incomple } & Average & -0.035 & 0.212 & 0.236 & 0.236 & -0.078 & 0.025 & 0.041 & 0.328 & -0.016 & 0.054 \\
\hline & St. & 1.06 & 0.857 & 0.933 & 0.925 & 1.11 & 1.17 & 0.940 & 1.01 & 0.975 & 0.857 \\
\hline \multirow[t]{2}{*}{ Complete } & Average & 0.005 & -0.035 & -0.039 & -0.039 & 0.013 & -0.004 & -0.006 & -0.054 & 0.002 & -0.009 \\
\hline & St. & 0.990 & 1.01 & 1.00 & 1.00 & 0.980 & 0.968 & 1.01 & 0.987 & 1.00 & 1.02 \\
\hline
\end{tabular}

As in the previous case, let's ignore the detailed analysis of the differences in mean values of personal factors of the subjects who are not statistically significant. Taking into account the nature of the results, we will summarize the tabular data based on the results of studying the significant differences in the level of personality factors of the subjects (Table 4).

Table 4

The statistical importance of the difference in the level of expression of personal factors of the subjects in accordance with their marital status

\begin{tabular}{|c|c|c|c|c|c|c|c|c|c|c|}
\hline & \multicolumn{10}{|c|}{ Personal factors } \\
\hline & 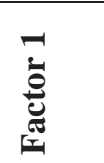 & 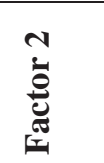 & 节 & 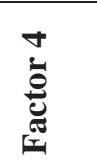 & 梯 & 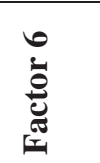 & & 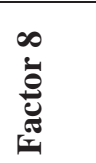 & 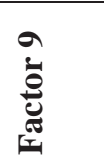 & 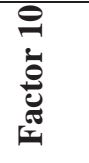 \\
\hline $\mathbf{P}$ & 0.880 & 0.016 & 0.050 & 0.059 & 0.720 & 0.953 & 0.678 & 0.014 & 0.994 & 0.532 \\
\hline
\end{tabular}

Taking into account the table data, it can be argued that reliable differences in the level of personality factors in the subjects with different family status were detected in relation to the «extravagant personality disposition» (Factor 8) $(\mathrm{p}<0.05)$, «the most powerful educational disposition» (Factor 2) $(\mathrm{p}<0.05)$ and «constructive educational support» (Factor 3$)(\mathrm{p}<0.05)$. Hardly falls into the zone of statistical significance of the factor «psychasthenic personal disposition» (Factor 4) $(\mathrm{p}=0.059)$, so in this case, one can restrict only to a general analysis of trends relevant to him.

Detailed analysis of data Table 3 reveals that in the study of single-parent families the average values of the factor of «extroverted personal disposition» (Factor 8) were significantly higher than those of the full families. In fact, the same pattern is characteristic of the factors of «indulgent educational disposition» (Factor 2) and «constructive educational patronage» (Factor 3). At the level of tendencies one can mention the factor of «psychasthenic personality disposition» (Factor 4), the average values of which were significantly more pronounced in the subjects from single-parent families.

If we take into account the meaningful characteristics of the first significant factor - the «extrovert personality disposition» (Factor 8) (Tables 3, 4), it becomes apparent that subjects from incomplete families are more likely than those surveyed from complete families to exhibit high degree of purposefulness, energy, independence, demonstration, egocentrism, openness for communication with people, extraversion. Such respondents in certain unfavorable circumstances are characterized by irritability, anger, authoritarianism, indifference to other people's grief, lack of empathy towards people, and others like that. Representatives of single-parent families to a greater extent than representatives of the complete ones, are characterized by perseverance and initiative, communicativeness and purposefulness, intelligence and activity, pronounced organizational skills, independence and willingness to take leadership; sociability, frankness, speed of switching in business and communication, benevolence. However, such subjects are characterized, to a greater extent than complete family members, by superficiality, inability to focus on a particular case or opinion, 
constant hustle, switching from one cause to another, disorganization, frivolity, readiness for unconscious risk; the complete irregularity of manifestations, dependence on others, and the lack of volitional control in the regulation of their own behavior. In general, it can be argued that investigated, representatives of single-parent families, are more oriented towards external aspects of reality compared to those surveyed from complete families (focus on social relationships, communication, etc.).

Next among the significant personal factors is «a powerful educational disposition» (Factor 2). Taking into account its meaningful characteristics (Tables 3, 4), it is obvious that representatives of single-parent families, as opposed to representatives of complete families, demonstrate a personalized guideline for the implementation of the strategy of intense protection in the field of child upbringing, primarily due to the expansion of the sphere of parental feelings. Such subjects are more prone to adoption and promotion in the family of the child's cult. They want the child to become more than just a child for them; so that it meets at least part of the needs that the complete family can provide in the psychological relationship of the spouses the needs for mutual extraordinary attachment. Hence - the risk of increased intense or dominant protection. Also, subject from single-parent families are more and more inclined towards maximal and uncritical satisfaction of any needs of the child - both material and spiritual and first of all in emotional contact with parents, communication with them, their love and attention; either do not use any forms of punishment at all, or they do so extremely rarely. Doubting the effectiveness of any punishment, such parents in the educational process are more likely to favor various forms of child promotion and stimulation. In general, it can be argued that the subjects - representatives of single-parent families - in comparison with those surveyed from complete families, are more likely to profess a sweeping strategy for raising the child with elements of increased protection. This «educational» pattern reflects the personal disposition of the studied from single-parent families for the upbringing of the child's qualities of uncritical permissiveness and availability of the object of desires and needs.

If we take into account the content characteristics of factor 3 - «constructive educational patronage», it becomes obvious that representatives of single-parent families, in contrast to the full ones, are characterized by a more pronounced level of parental protection in the upbringing of the child. For them, to a greater extent than for representatives of complete families, a positive attitude towards the child is typical, a desire to take an active part in the upbringing of the child, to devote a lot of time, strength and attention, to make the upbringing of the child a sense of all life; to accept the child as it is, to respect and recognize its personality, to approve its interests, to support its plans, to spend enough time with it. Such parents are more likely to show a tendency to cooperate with the child, to encourage its autonomy and initiative; the desire to be equal with it, to reduce as much as possible the psychological distance between themselves and the child, to be closer to it, to satisfy its basic intelligent needs, to protect from troubles, etc. However, parents - representatives of singleparent families, as opposed to representatives of complete families, with a higher risk of occurrence, will show hypochondria in relation to the child. The «weak spots» of such parents are increased insecurity, fear of error, exaggerated perceptions about the sickliness of a child. On the basis of the abovementioned, it can be assumed that the subjects - representatives of single-parent families - are more oriented towards a constructive and responsible parental attitude not only to their duties as parents but first and foremost to the child: its needs, interests, hobbies, etc. Such «educational» disposition reflects the personal approach of parents to the child's upbringing of humanity, empathy, compassion that is, those character traits that determine the moral development of the individual. In order to complete this research block by a general analysis of the revealed tendencies in relation to the factor of psychasthenic personal disposition (Factor 4), for which the level of reliability almost reached the zone of statistical significance, we can note that its average values were significantly more pronounced in the subjects from incomplete families. In terms of meaningful interpretation, we should note that the subjects from the incomplete families were observed with the dominant worrythoughtful tendencies with the manifestation of constant insecurity, indecision, timidity and vulnerability. 
The next step in our analysis was to compare the average values of the personal factors of parents with problem children for their age differences. This allowed us to identify a number of trends important for our study. So, depending on the age, the average values of their personal factors were distributed as follows (Table 5).

Table 5

The average values of personal factors of the subjects depending on the age

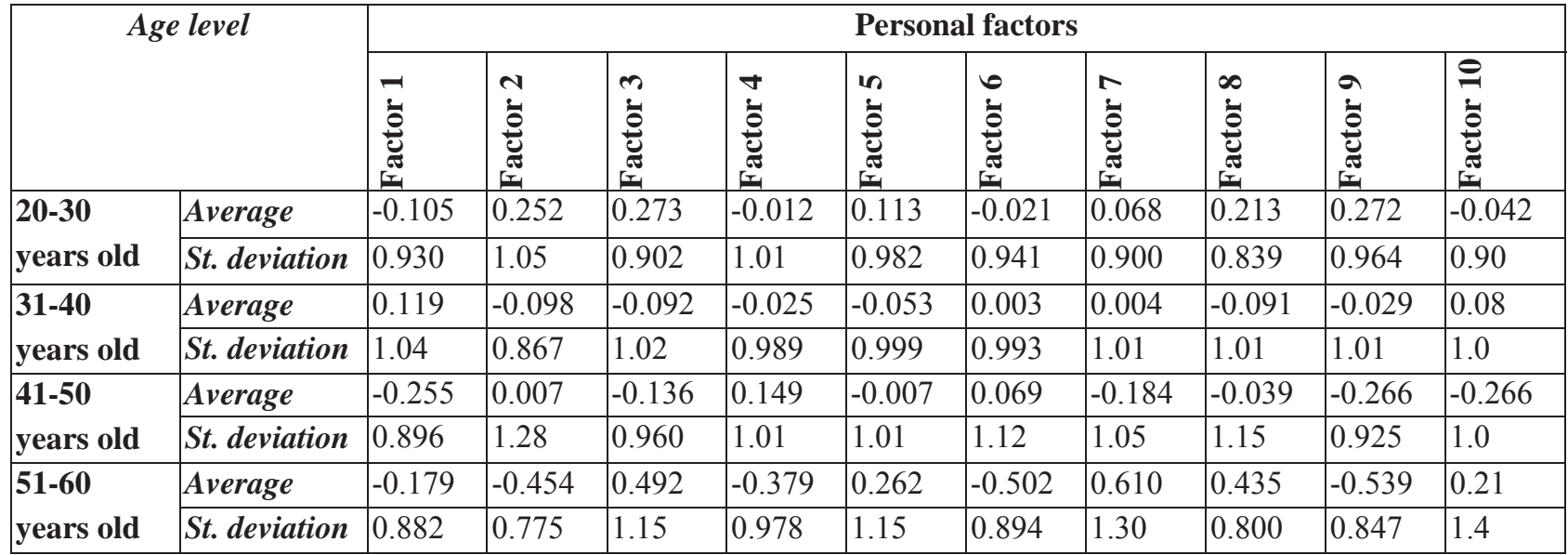

With further interpretation of the revealed trends, ignore the detailed analysis of the differences in the mean values of the individual factors of the subjects who are not statistically significant. Also, given the nature of the results obtained, the average values of the factor estimates presented in the units of the standard deviation, - the compilation of the table data correctly will be carried out using the results of studying the significant differences in the level of severity of personal factors of the subjects (Table 6).

Table 6

Statistical importance of the differences in the level of the expression of the personal factors depending on the age

\begin{tabular}{|c|c|c|c|c|c|c|c|c|c|c|}
\hline & \multicolumn{10}{|c|}{ Personal factors } \\
\hline & 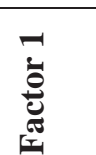 & 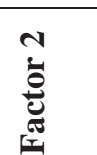 & 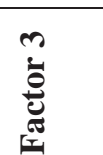 & 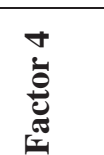 & 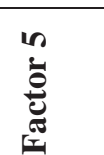 & 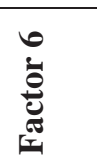 & 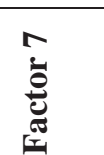 & 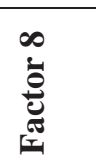 & 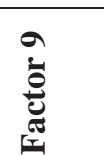 & 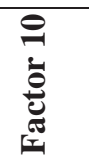 \\
\hline $\mathbf{P}$ & 0.619 & 0.013 & 0.000 & 0.592 & 0.279 & 0.890 & 0.063 & 0.106 & 0.000 & 0.377 \\
\hline
\end{tabular}

According to the tabular data, the significant differences in the level of severity of personality factors in the subjects of different ages were found regarding «constructive educational support» (Factor 3$)(p<0.001)$, «introverted pedantic personal disposition» (Factor 9) $(\mathrm{p}<0.001)$, and «Indulgent educational disposition» (Factor 2) $(\mathrm{p}<0.05)$. Also, the level of statistical significance is possessed by the factor of «dominantly aggressive personal disposition» (Factor 7) was quite close to the zone of significant indicators ( $\mathrm{p}=0.063$ ). Summarizing the data of Table 5, we can state that the age dynamics of changes in average values of personality factors studied, which turned out to be statistically significant, has different character - both linear and nonlinear. Thus, it is obvious that the factor of «constructive educational support» (Factor 3) reaches the highest average values in the oldest age category of subjects (51-60 years old), receiving the peak of the lowest average values in the studied age group of 41-50 years old. According to the data, the representatives of the oldest age group of parents (51-60 years old), compared with representatives of younger age groups, especially the age group 41-50 years old (the lowest average factor of the factor), show a more pronounced level of parental protection in the upbringing of the child. They, to a greater extent than for representatives of other 
age groups of parents, are characterized by a positive attitude towards the child, the desire to take an active part in the upbringing of the child, to devote a lot of time, strength and attention; to accept the child as it is, to respect and recognize its personality, to approve its interests, to support its plans, to spend enough time with it.

Parents of the oldest age group (51-60 years old), unlike the representatives of younger age groups, especially the category of 41-50 years old, are more likely to show a desire to cooperate with the child, to encourage its independence and initiative; the desire to be equal with it, to reduce as much as possible the psychological distance between themselves and the child, to be closer to it, to satisfy its basic intelligent needs, to protect from troubles, etc. However, the elderly parents, unlike the younger ones, will have hypochondriac guidelines in relation to the child, with a higher risk. «Weak spot» of such parents - increased insecurity, fear of error, exaggerated perceptions about the pain of a child. On the basis of this it can be argued that parents of the oldest age group in comparison with parents of younger age groups are more oriented towards a constructive and responsible parental attitude not only to their duties as parents but, first of all, to the child: its needs, interests, hobbies, etc.

With regards to the factor of «introverted-pedantic personal disposition» (Factor 9), we observe a pronounced linear character of age dynamics - the peak of the highest average values of the factor reaches the youngest age category of parents (20-30 years old), gradually moving to the level of the lowest average values of the factor in the oldest age group of subjects (51-60 years old). Given the strict linear character of the age dynamics of this personality factor, we can assume that the change in its content characteristics with age is subject to the logic of age-related development of man, and is to a greater extent a natural than socially deterministic process. However, the refinement of this hypothesis requires a larger base of empirical evidence and is not the direct object of our study. Given the essential characteristics that identify the content of this factor, it can be found that the representatives of the youngest category of parents (20-30 years) show a high level of conservative pedantism based on personal introverted orientation. In particular, the youngest parents show love for order, conservatism (do not recognize what has not yet been accepted by others); high energy, diligence, cleanliness, serviceability, care, reliability, punctuality, attentiveness to their health. Their dominant characteristics are cleanliness, discipline, modesty, complacency, diligence, friendliness, no maliciousness. At the same time, they are more likely than representatives of other age groups of parents to have such characteristics as: high degree of isolation, restraint, fixation of interests on the phenomena of their inner world, increased fatigability, irritability, predisposition to hypochondria; often closed, fencing, low empathy, seriousness, impenetrability, lack of words, stability of interests, continuity of occupations; often impartiality, isolation, emotional coldness, etc.

The change in the average values of the personal factor of the «indulgent educational disposition» (Factor 2) is quite linear in its character, since the highest level of its average values is observed in the youngest age group of the subjects (20-30 year olds), and the peak of the lowest average values is observed among representatives of the oldest age category (51-60 year olds), and at the level of two intermediate age groups (31-40 and 41-50), we observe the change in the mean values of the factor that is inappropriate to the general age-old trend. Given the meaningful characteristics, it is obvious that the representatives of the youngest age group of the subjects (20-30 year olds), in contrast to representatives of older age groups, demonstrate some personal tendencies towards the implementation of the strategy of intense protection in the field of child upbringing, primarily due to the expansion of the sphere of parental feelings. Parents of the youngest age group are, to a greater extent than parents of other age groups, prone to the adoption and promotion of «cult of a child»; they want the child to become more than just a child for them; so that it meets the need for mutually exclusive attachment. Hence - the risk of increased intense or dominant protection. Also, the youngest ones are more likely to seek maximum and uncritical satisfaction of any needs of the child - both material and spiritual, first of all, in emotional contact with parents, communication with them, their love and attention; they either do not use any forms of punishment at all, or they do so extremely rarely. Concerned with the 
effectiveness of any punishment, young parents in the educational process are more likely to favor a variety of forms of child promotion and stimulation. In general, it can be argued that representatives of the youngest age group of parents compared with older parents are more likely to profess the indulgent strategy for raising the child with elements of increased protection; often the «educational» pattern of the youngest parent sample involves raising the child's qualities of uncritical permissiveness and availability of the object of desires and needs.

The next stage of our study was related to the definition of statistically significant differences in the level of personality factors of the subjects being differentiated according to the criterion of family functioning (pseudo-functional, dysfunctional, functional family). This allowed us to identify a number of important patterns for our analysis. Thus, depending on the level of family functioning, the average values of personality factors of the subjects were distributed as follows (Table 7).

Table 7

The average values of the personal factors of the subjects depending on the level of family functioning

\begin{tabular}{|c|c|c|c|c|c|c|c|c|c|c|c|}
\hline \multirow{2}{*}{\multicolumn{2}{|c|}{$\begin{array}{l}\text { The level of family } \\
\text { functioning }\end{array}$}} & \multicolumn{10}{|c|}{ Personal factors } \\
\hline & & 를 & 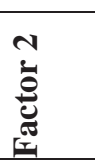 & 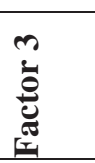 & 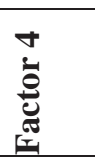 & 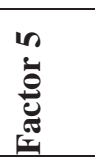 & 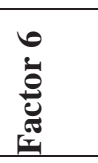 & ¿ே. & 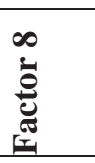 & ẫ & 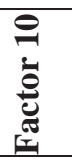 \\
\hline \multirow{2}{*}{$\begin{array}{l}\text { Pseudo- } \\
\text { functional }\end{array}$} & Average & - & 0.164 & 0.052 & 0.212 & - & 0.011 & 0.034 & 0.277 & - & 0.06 \\
\hline & St. & 1.05 & 0.865 & 0.904 & 0.938 & 1.10 & 1.16 & 0.936 & 1.03 & 0.977 & 0.84 \\
\hline \multirow{2}{*}{$\begin{array}{l}\text { Dysfunctiona } \\
\text { I family }\end{array}$} & Average & 0.109 & 0.175 & - & - & 0.079 & - & 0.099 & - & 0.214 & 0.12 \\
\hline & St. & 0.976 & 0.937 & 1.12 & 0.927 & 0.932 & 0.966 & 0.977 & 0.943 & 1.08 & 1.10 \\
\hline \multirow{2}{*}{$\begin{array}{l}\text { Functional } \\
\text { family }\end{array}$} & Average & - & - & 0.245 & 0.004 & - & 0.001 & - & - & - & - \\
\hline & St. & 0.995 & 1.04 & 0.949 & 1.03 & 1.00 & 0.975 & 1.02 & 1.00 & 0.959 & 0.98 \\
\hline
\end{tabular}

With further interpretation of the revealed trends, let's ignore the detailed analysis of the differences in the mean values of the individual factors of the subjects who are not statistically significant. Also, given that the average values of factor estimates are presented in standard deviation units, we will generalize the data of the table using the results of statistical analysis (Table 8).

Table 8

Statistical significance of the difference in the levels of expression of personal factors of the subjects in accordance with the level of family functioning

\begin{tabular}{|c|c|c|c|c|c|c|c|c|c|c|}
\hline & \multicolumn{10}{|c|}{ Personal factors } \\
\hline & 节 & 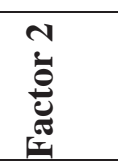 & 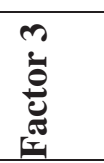 & 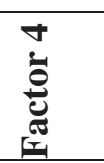 & 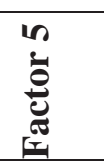 & 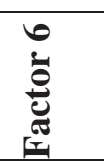 & ז̃ & 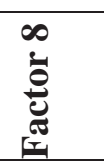 & ầ & 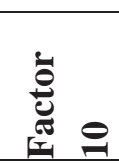 \\
\hline $\mathbf{P}$ & 0.538 & 0.002 & 0.017 & 0.075 & 0.314 & 0.981 & 0.125 & 0.110 & 0.021 & 0.159 \\
\hline
\end{tabular}

According to the data in the table, statistically significant differences in the level of expressiveness of personality factors in the subjects with different levels of family functioning were detected in relation to the «major educational disposition» (Factor 2) ( $\mathrm{p}<0.01)$, «constructive educational support» (Factor 3$)(\mathrm{p}<0.05)$ and «introverted-pedantic personal disposition» (Factor 9) $(\mathrm{p}<0.05)$. According to tabular data, the personal factor of the «major educational disposition» (Factor 2) was the most pronounced in the representatives of dysfunctional and pseudo-functional families. In this case, representatives of these types of family functioning demonstrate a personalized guideline for the implementation of a comprehensive protection strategy in the field of child upbringing. They are more likely than the representatives of the functional family, tend to adopt 
and promote the cult of the child; They want the child to become more than just a child for them; so that it meets the need for mutual adherence; strive for maximum and uncritical satisfaction of any needs of the child - both material and spiritual, first of all, in emotional contact, communication, love and attention; Do not use any forms of child punishment, or they do it extremely rarely. In general, it can be argued that representatives of dysfunctional and pseudo-functional types of family functioning in comparison with representatives of a normally functioning family are more likely to profess the indulgent strategy of raising a child with elements of increased protection, which may lead to the child's development of a sense of uncritical permissiveness and the availability of any object of desires and needs.

The next among significant personal factors is «constructive educational patronage» (Factor 3). According to the data in the table, this personality factor was most pronounced in the representatives of a normally functioning family. In such subjects compared with other types of family functioning, especially the dysfunctional family, a more pronounced level of parental protection in the upbringing of the child is manifested. For them, to a greater extent than for representatives of other types of family functioning, a positive attitude towards the child is characteristic, the desire to take an active part in the upbringing of the child, spend a lot of strength and attention on it; to accept the child as it is, to respect and recognize its personality, to approve its interests, to support its plans, to spend enough time with it.

Such parents have a greater tendency to cooperate with the child, to encourage its autonomy and initiative; the desire to be equal with it, optimize the psychological distance between themselves and the child, be closer to it, satisfy its basic intelligent needs, protect from troubles, etc. This suggests that in a normally functioning family compared with pseudo- and dysfunctional, parents are more oriented towards a constructive and responsible attitude not only to their duties as parents but, first of all, to the child itself: its needs, interests, hobbies, etc.

The next level of significance is the personal factor of «introverted-pedantic personal disposition» (Factor 9). According to table data (see Table 7-8) and taking into account its informative characteristics, it is obvious that representatives of normally functioning families, in contrast to dysfunctional ones, demonstrate a higher level of conservative pedantry on the basis of personal introverted orientation. Particularly, parents with this type of family functioning demonstrate love for order, conservatism (do not recognize what has not yet been accepted by others); are characterized by high energy intensity, diligence, punctuality, reliability, and attention to their health. Their dominant characteristics are cleanliness, discipline, modesty, complacency, diligence, friendliness, lack of maliciousness. At the same time, they have more characteristics than those of other types of family functioning, such as: high degree of isolation, restraint, fixation of interests on the phenomena of their inner world, increased fatigability, irritability, tendency to hypochondria; often closed, isolation, low empathy, seriousness, impenetrability, lack of words, stability of interests, continuity of occupations; often impartiality, emotional coldness, etc.

5. Conclusions. Summarizing the interim results, we note that:

1. The statistical analysis of differences in the level of personality factors in the subjects of different sex and age, as well as with different family status (incomplete, complete family) and type of family functioning (pseudo-functional, dysfunctional, functional family), allowed to reveal important patterns.

2. In particular, reliable differences in the level of personality factors in the subjects of different sexes were found in relation to «constructive educational protection» $(\mathrm{p}<0.001)$, «indulgently indifferent personal disposition» $(\mathrm{p}<0.05)$, «passive-protective personal disposition» $(\mathrm{p}<0.05)$ and «psychosthenic personal disposition» $(\mathrm{p}<0.05)$.

3. Also, statistically significant differences in the level of personality factors in the subjects with different family status were detected in relation to «extroverted personality disposition» $(\mathrm{p}<0.05)$, «the indulgent educational disposition» $(\mathrm{p}<0.05)$ and «constructive educational support» $(\mathrm{p}<0.05)$.

4. According to the results of the statistical analysis of age characteristics of the expressiveness of the personal factors of the parents of the problem children, statistically significant differences were identified 
according to the factor of «constructive educational protection» $(\mathrm{p}<0.001)$, «introverted-pedantic personal disposition» $(\mathrm{p}<0.001)$ and «indulgent educational disposition» $(\mathrm{p}<0.05)$.

5. Finally, the statistical analysis of the indicators of the severity of personality factors in the subjects with different types of family functioning allowed to reveal statistically significant differences in a number of factors: «major educational disposition» $(\mathrm{p}<0.01)$, «constructive educational protection» $(\mathrm{p}<0.05)$, and «introverted-pedantic personal disposition» $(\mathrm{p}<0.05)$.

\section{REFERENCES}

Byul A., Tofel P. (2002). SPSS. Искусство обработки информачии: анализ статистических данных $u$ восстановление скрытых закономерностей: пер. с нем [Art of information processing: analysis of statistical data and the restoration of hidden patterns: Transl. from Germ.]. St. Petersburg: Diasoft YUG LLC. (in Russian).

Eidemiller E., Yusitskis V. (2009). Психология и психотерапия семьи [Family psychology and psychotherapy]. St. Petersburg: Peter. (in Russian).

Garbuzov V.I., Fesenko Yu.F., (2013). Неврозы у детей [Neurosis in children]. Moscow: Kogito-Center. (in Russian).

Mamaychuk I.I. (2006). Психокоррекционные технологии для детей с проблемами в развитии [Psychocorrectional technologies for children with developmental problems]. St. Petersburg: Rech. (in Russian).

Nasledov A.D. (2004). Математические методы психологического исследования: анализ и интерпретация данных [Mathematical methods of psychological research: analysis and interpretation of data]. St. Petersburg: Speech. (in Russian).

Nasledov A.D. (2005). SPSS: компьютерный анализ данных в психологии и соииальных науках [SPSS: Cотритеr Analysis of Data in Psychology and Social Sciences]. St. Petersburg: Peter. (in Russian).

Rechitskaya E.G., Puzanov B.P., Bogdanova T. (2012). Психолого-педагогическое сопровождение лиц с наручением слуха. Учебное пособие для ВУЗов [Psychological and pedagogical support of persons with hearing impairment. Textbook for universities]. Moscow: Prometheus. (in Russian).

Semago N.Ya., Semago M. M. (2000). Проблемные дети: Основы диагностической и коррекционной работы психолога [Problem children: Basics of diagnostic and correctional work of a psychologist]. Moscow: ARKTI. (in Russian).

Schmidt V.R. (2007). Psychological Assistance to Parents and Children: Training Programs. Moscow: TU Sphere.

Varga A. (2000). Теория семейных систем Мюррея Боуэна. Основные понятия, методы и клиническая практика [Murray Bowen Family Systems Theory. Basic concepts, methods and clinical practice]. Moscow: KogitoCenter. (in Russian).

Yatsenko T.S. (2015). Динамика развития глубиной психокоррекиии: теория и практика [The dynamics of the development of psycho-correction depth: theory and practice]. Dnepropetrovsk: Innovation. (in Russian).

Zakharov A.I. (2010). Дневные и ночные страхи детей [Day and night fears of children]. St. Petersburg: Rech. (in Russian). 